\title{
Execução antecipada da pena: entre a garantia do estado de inocência, a coisa julgada e as teorias absolutas da pena
}

\author{
Early implementation of the penalty: \\ between the guarantee of the state of innocence, \\ res judicata and the absolute theories of the penalty
}

\section{Décio Franco David ${ }^{1}$}

\author{
Universidade Estadual do Norte do Paraná - Jacarezinho/Paraná \\ decio@dfdavid.com \\ http://lattes.cnpq.br/4417997720081911 \\ http://orcid.org/0000-0001-7284-3910
}

\begin{abstract}
Gilson Bonato ${ }^{2}$
Faculdade de Educação Superior do Paraná - Curitiba/Paraná gilson@bonato.adv.br

http://lattes.cnpq.br/0710153947450817

http://orcid.org/0000-0001-9303-0214
\end{abstract}

1 Doutorando em Ciência Jurídica pela Universidade Estadual do Norte do Paraná - Linha de Pesquisa: Função Política do Direito (início em 2016). Mestre em Direito Penal pela Universidade de São Paulo (2016). Mestre em Ciência Jurídica pela Universidade Estadual do Norte do Paraná - Linha de Pesquisa: Função Política do Direito (2014). Pós-graduado em Gestão de Direito Empresarial pela FAE Centro Universitário (2009). Graduado em Direito pela Universidade Estadual de Ponta Grossa (2008). Professor Substituto de Direito Penal da Universidade Federal do Paraná (UFPR). Professor de Direito Penal da FAE Centro Universitário. Professor de Direito Penal da Faculdade de Educação Superior do Paraná (FESPPR). Professor de diversos cursos de Pós-graduação (lato sensu) em Direito Penal e Processual Penal. Advogado.

2 Doutor em Direito pela Universidade Federal do Paraná (2008). Graduado em Direito pela Pontifícia Universidade Católica do Paraná (1993) e em Filosofia pela Pontifícia Universidade Católica do Paraná (1987). Mestre em Direito Econômico e Social pela Pontifícia Universidade Católica do Paraná (2002). Estágio em pós-doutoramento pela Universidade de Coimbra (2012). Professor Titular de Direito Processual Penal e Coordenador do Curso de Direito da Faculdade de Educação Superior do Paraná (FESPPR), mantida pela Fundação de Estudos Sociais do Paraná (FESP). Professor e Coordenador do Curso de Direito da Faculdade Secal. Advogado criminalista. 
Resumo: O presente trabalho analisa o julgamento do Habeas Corpus $\mathrm{n}^{\circ}$ 126.292/SP, no qual o Supremo Tribunal Federal decidiu pela possibilidade da execução antecipada da pena quando houver decisão confirmatória da condenação em Segundo Grau de Jurisdição. O trabalho foi desenvolvido sob o método dedutivo, tendo como técnica a documentação indireta com fontes secundárias (pesquisa bibliográfica). O trabalho objetiva responder a duas indagações: 1) a execução antecipada de pena pode mudar os conceitos de coisa julgada e presunção de inocência?; 2) a execução antecipada de pena corresponde ao retorno das teorias absolutas da pena? Em síntese, o artigo almeja demonstrar o desacerto da decisão sob o recorte dos argumentos centrais apresentados no julgado, compreendendo que há inicialmente uma dificuldade de compreensão quanto à natureza jurídica da garantia do estado de inocência, e, ao final, demonstrando como a decisão fere o conceito de coisa julgada e reforça as teorias absolutas da pena.

Palavras-chave: Presunção de Inocência; Normas regras e normas princípios; Teorias absolutas da pena.

ABSTRACT: This paper analyses the judgment of habeas corpus number 126.292/SP, in which the Federal Supreme Court decided for the possibility of early execution of the penalty when there is a confirmatory decision of the conviction in Second Degree of Jurisdiction. The work has developed under the deductive method, having as technique the indirect documentation with secondary sources (bibliographic research). The paper aims to demonstrate the mismatch of the decision under the cut of the central arguments presented in the judgment, understanding that there is, initially, a difficulty of understanding as to the legal nature of the guarantee of the state of innocence and, at the end, demonstrating how the decision hurts the concept of res judicata and reinforces the absolute theories of punishment. KEY-WORDS: Presumption of innocence; Legal rules and principles; Absolute theories of punishment.

SUMÁRIO: 1 Introdução: O caso - 2 Natureza jurídica da presunção de inocência: norma princípio ou norma regra? - 30 estado de inocência como garantia processual decorrente do princípio da culpabilidade - 4 Antecipação da execução da pena: Um retorno às teorias absolutas da pena e a deturpação do sistema penal integrado -Considerações finais - Referências Bibliográficas. 
"Se temos que obedecer a certos princípios básicos do Direito Penal e a certos princípios constitucionais, não podemos, por razões supralegais, em determinados casos, deixá-los de lado. Ou os empregamos em todos os casos, ou os rejeitamos". (Ministro Felix Fischer em voto no Recurso Especial no 213.064/SP)

\section{INTRODUÇÃO: O CASO}

Em 17 de fevereiro de 2016, o Supremo Tribunal Federal decidiu, por maioria de votos no julgamento do Habeas Corpus $\mathrm{n}^{\circ} 126.292 /$ SP, que a pendência de recursos Especial ou Extraordinário não obsta 0 cumprimento prévio de pena privativa de liberdade.

Segundo o Ministro Relator, Teori Zavascki, a execução da pena na pendência de recursos de natureza extraordinária "não compromete o núcleo essencial do pressuposto da não-culpabilidade, na medida em que o acusado foi tratado como inocente no curso de todo o processo ordinário criminal, observados os direitos e as garantias a ele inerentes, bem como respeitadas as regras probatórias e o modelo acusatório atual”'. Em outras palavras, para o Ministro, a presunção de inocência estaria exaurida no segundo grau de jurisdição ordinário, haja vista a impossibilidade de debate das provas em sede de recursos especial e extraordinário ${ }^{4}$. Acompanharam o relator os ministros Edson Fachin, Luís Roberto Barroso, Luiz Fux, Dias Toffoli, Cármen Lúcia e Gilmar Mendes. Divergiram os ministros Rosa Weber, Marco Aurélio, Celso de Mello e Ricardo Lewandowski.

O posicionamento adotado em 2016 modifica o antigo entendimento da Corte, o qual fora sedimentado pela decisão do Plenário no Habeas Corpus 84.078/MG, realizado em 05 de fevereiro de 2009. Nesse julgado, relatado pelo então Ministro Eros Grau, assentou-se, por sete votos a quatro, que o princípio da presunção de inocência se

3 Página 08 do voto do Ministro no alusivo habeas corpus.

4 "Os julgamentos realizados pelos Tribunais Superiores não se vocacionam a permear a discussão acerca da culpa, e, por isso, apenas excepcionalmente teriam, sob o aspecto fático, aptidão para modificar a situação do sentenciado" (p. 13 do voto). 
mostra incompatível com a execução da sentença antes do trânsito em julgado da condenação.

O novo entendimento tornou-se cediço em todo o sistema jurídico nacional, de modo que os principais argumentos favoráveis à decisão foram a necessidade de garantir uma efetividade da persecução criminal, evitar a prescrição e, de certo modo, evitar recursos protelatórios que impeçam a execução da pena.

Em que pese o entendimento apresentado pelos sete ministros que decidiram pela possibilidade de execução antecipada da pena, tal postura contraria regras constitucionais (em especial o conceito de coisa julgada e a presunção de inocência) e representa uma nova faceta das teorias absolutas da pena, distorcendo a própria finalidade da atividade estatal de exercer o controle social do intolerável ${ }^{5}$. Nesse espeque, o presente trabalho tem por objetivo apontar como o novo posicionamento infringe não apenas a presunção de inocência e o conceito de coisa julgada, mas serve de efeito simbólico a uma nova ânsia punitiva estatal embalada por um verdadeiro fetiche popular ${ }^{6}$ sobre a esfera penal e processual penal.

\section{Natureza JURÍdicA da PRESUNÇÃo de INOCÊNCIA: NORMA PRINCÍPIO OU NORMA REGRA?}

Como bem afirma José de Faria Costa, todo ramo científico jurídico necessita de um objeto diferenciado e autônomo, uma metodologia própria e princípios específicos ${ }^{7}$ que orientem os rumos dogmáticos de compreensão e estudo da área. Em outras palavras, todo conhecimento científico ou filosófico resulta da existência de princípios ${ }^{8}$, os quais podem

5 Sobre o assunto, BUSATO, Paulo César. Por que, afinal, aplicam-se penas? In: SCHMIDT, Andrei Zenkner. Novos Rumos do Direito Penal Contemporâneo Livro em homenagem ao Prof. Dr. Cezar Roberto Bittencourt. Rio de Janeiro: Lumen Juris, 2006, p. 522.

6 Acerca da correlação entre fetiche e pena, DAVID, Décio Franco; SALOMÃO NETO, Antônio. Fetichismo e Pena: Reflexões sobre psicanálise no Direito Penal. Revista O Mal-Estar no Direito, v. 2, n. 2. Set./2016, p. 1-17.

7 COSTA, José de Faria. Direito Penal Económico. Coimbra: Quarteto, 2003, p. 19-20.

8 Informa-se que a classificação aqui adotada segue posturas já apresentadas anteriormente em: DAVID, Décio Franco. Fundação..., Op. cit., p. 153 e ss; 
ser definidos como "enunciados lógicos admitidos como condição ou base de validade das demais asserções que compõem dado campo do saber".

Para Miguel Reale, os princípios podem ser divididos em três categorias: a) omnivalentes ${ }^{10}$; b) plurivalentes ${ }^{11}$; c) monovalentes ${ }^{12}$. Para ele, os princípios gerais de direito são "enunciações normativas de valor genérico, que condicionam e orientam a compreensão do ordenamento jurídico, quer para a sua aplicação e integração, quer para a elaboração de novas normas"13. Os princípios não são meros "preceitos de ordem moral ou econômica, mas sim esquemas que se inserem na experiência jurídica, convertendo-se, desse modo, em elementos componentes do Direito" ${ }^{14}$.

Por outro lado, Reale define norma jurídica como "uma estrutura proposicional enunciativa de uma forma de organização ou de conduta, que deve ser seguida de maneira objetiva e obrigatória” ${ }^{15}$. Deste modo, a norma jurídica terá como características a natureza objetivo/ heterônoma (que significa estar com ou contra a vontade de todos) e a exigibilidade/obrigatoriedade daquilo que enuncia ${ }^{16}$. Destaca-se que

DAVID, Décio Franco; ZAMBIAZI, Larissa Horn; DRUMMOND, Fernanda Guerra. Relação entre normas e princípio no Sistema Penal. In: Paulo César Busato. (Org.). Fundamentos de Direito Penal (Série Direito Penal Baseado em Casos). Curitiba: Juruá, 2013, p. 71-92.

9 REALE, Miguel. Lições preliminares de Direito. 27. ed. São Paulo: Saraiva, 2010, p. 303.

10 "Quando são válidos para todas as formas de saber, como é o caso dos princípios de identidade e de razão suficiente" (REALE, Miguel. Op. cit., p. 304).

11 "Quando aplicáveis a vários campos de conhecimento, como se dá com o princípio da causalidade, essencial às ciências naturais. Mas não extensivo a todos os campos do conhecimento" (REALE, Miguel. Loc. cit).

12 São aqueles que "só valem no âmbito de determinada ciência, como é o caso dos princípios gerais de direito” (REALE, Miguel. Loc. cit).

REALE, Miguel. Op. cit., p. 304

REALE, Miguel. Op. cit., p. 306.

REALE, Miguel. Op. cit., p. 95. “Dizemos que a norma jurídica é uma estrutura proposicional porque o seu conteúdo pode ser enunciado mediante uma ou mais proposições entre si correlacionadas, sendo certo que o significado pleno de uma regra jurídica só é dado pela integração lógico-complementar das proposições que nela se contêm. Afirmamos que uma norma jurídica núncia um dever ser porque nenhuma regra descreva algo que é, mesmo quando, para facilidade de expressão, empregamos o verbo ser" (REALE, Miguel. Loc. cit).

16 REALE, Miguel. Op. cit., p. 93. 
para Reale norma e regra são palavras sinônimas, uma vez que se refere aos dois termos de forma indistinta ${ }^{17}$.

Já para Robert Alexy ${ }^{18}$ e Virgílio Afonso da Silva ${ }^{19}$, as normas constituem um gênero do qual os princípios e as regras são espécies. Para tanto, fazem uma análise detalhada sobre os critérios distintivos dos princípios e das regras.

O primeiro critério de distinção, o qual é utilizado em grande escala, é o da generalidade, segundo o qual "princípios são normas com grau de generalidade relativamente alto, enquanto o grau de generalidade das regras é relativamente baixo" ${ }^{20}$. O autor alemão ainda indica que inúmeros critérios podem ser utilizados para a diferenciação, os quais acabam por desembocar em três teses específicas para tal fim ${ }^{21}$.

A primeira tese sustenta que não tem como diferenciar princípios de regras. Assim, qualquer tentativa "seria, diante da diversidade existente, fadada ao fracasso" ${ }^{2}$. A segunda tese vale-se dos graus inerentes às normas, isto é, "os adeptos dessa tese são sobretudo aqueles vários autores

17 REALE, Miguel. Op. cit., Capítulos IX a XI, p. 93 - 138.

18 ALEXY, Robert. Teoria dos Direitos Fundamentais. 2. ed. São Paulo: Malheiros, 2011.

19 SILVA, Virgílio Afonso da. Direitos Fundamentais: conteúdo essencial, restrições e eficácia. 2. ed. São Paulo: Malheiros, 2011.

20 ALEXY, Robert. Op. cit., p. 87.

21 “Outros critérios discutidos são a ‘determinabilidade dos casos de aplicação', a forma de seu surgimento - por exemplo, por meio da diferenciação entre normas 'criadas' e normas 'desenvolvidas' - o caráter explícito de seu conteúdo axiológico, a referência à idéia de direito ou a uma lei jurídica suprema e a importância para a ordem jurídica. Princípios e regras são diferenciados também com base no fato de serem razões para regras ou serem eles mesmos regras, ou ainda. No fato de serem normas de argumentação ou normas de comportamento" (ALEXY, Robert. Op. cit., p. 88-89). "Há autores que sustentam que entre regras e princípios há uma diferença de grau. A partir dessa idéia, há aqueles que sustentam que o que distingue ambos seria o grau de importância: princípios seriam as normas mais importantes de um ordenamento jurídico, enquanto as regras seriam aquelas normas que concretizariam esses princípios. Há também aqueles que distinguem ambos a partir do grau de abstração e generalidade: princípios seriam mais abstratos e mais gerais que as regras. Outras classificações baseadas em algum tipo de gradação são possíveis" (SILVA, Virgílio Afonso da. Op. cit., p. 44).

22 ALEXY, Robert. Op. cit., p. 89. 
que vêem no grau de generalidade o critério decisivo para a distinção"23. A terceira tese defende que além da diferença de grau existe uma diferença qualitativa, esta é a tese utilizada por $\mathrm{Alexy}^{24}$. Deste modo, o autor afirma que "o ponto decisivo na distinção entre regras e princípios é que princípios são normas que ordenam que algo seja realizado na maior medida possível dentro das possibilidades jurídicas e fáticas existentes"25.

Na mesma toada, Virgílio Afonso da Silva afirma que de acordo com a teoria dos princípios, a diferenciação ocorre pela "estrutura dos direitos que essas normas garantem". Assim, "no caso das regras, garantemse direitos (ou se impõem deveres) definitivos, ao passo que no caso dos princípios são garantidos direitos (ou são impostos deveres) prima facie" 26 .

Consequentemente, "se um direito é garantido por uma norma que tenha a estrutura de uma regra, esse direito é definitivo e deverá ser realizado totalmente, caso a regra seja aplicável ao caso concreto" ${ }^{27}$, ou seja, a regra é sempre aplicada no caso concreto, inclusive no pertinente a sua exceção. Já no condizente aos princípios "não se pode falar em realização sempre total daquilo que a norma exige" ${ }^{28}$, sendo que muitas vezes se dá de forma parcial. Isso ocorre "porque no caso dos princípios há uma diferença entre aquilo que é garantido (ou imposto) prima facie e aquilo que é garantido (ou imposto) definitivamente"29.

Nessa esteira, Alexy conceitua princípios como mandamentos de otimização, os quais são caracterizados por "poderem ser satisfeitos em graus variados e pelo fato de que a medida devida de sua satisfação não depende somente das possibilidades fáticas, mas também das possibilidades jurídicas" ${ }^{30}$, em outras palavras, seu uso será o mais amplo possível.

Por outro lado, define que as regras servem para restringir a aplicação da norma, ou seja, são “determinações no âmbito daquilo que

\footnotetext{
23 ALEXY, Robert. Op. cit., p. 90.

24 ALEXY, Robert. Loc. cit.

25 ALEXY, Robert. Loc. cit.

26 SILVA, Virgílio Afonso da. Op. cit., p. 45.

27 SILVA, Virgílio Afonso da. Loc. cit.

28 SILVA, Virgílio Afonso da. Loc. cit.

29 SILVA, Virgílio Afonso da. Loc. cit.

30 ALEXY, Robert. Loc. cit.
} 
é fática e juridicamente possível" 31 , logo, "as regras são normas que são sempre ou satisfeitas ou não satisfeitas. Se uma regra vale, então deve se fazer exatamente aquilo que ela exige; nem mais, nem menos"32.

Diante de tais considerações, verifica-se que a presunção de inocência não detém conteúdo normativo suficiente para ser considerado um princípio, embora, não raras vezes, seja assim chamado pela doutrina e jurisprudência. Em verdade, apura-se que a densidade normativa da presunção de inocência corresponde a uma norma regra ${ }^{33}$, pois não admite a ductilidade atribuída aos comandos normativos principiológicos ${ }^{34}$.

31 ALEXY, Robert. Op. cit., p. 91.

32 ALEXY, Robert. Loc. cit.. Além disso, Destaca Virgílio Afonso da Silva que "O elemento central da teoria dos princípios de Alexy é a definição de princípios como mandamentos de otimização. Para ele, princípios são normas que exigem que algo seja realizado na maior medida possível diante das possibilidade fáticas e jurídicas existentes. Isso significa, entre outras coisas, que, ao contrário do que ocorre com as regras jurídicas, os princípios podem ser realizados em diversos graus. A idéia regulativa é a realização máxima, mas esse grau de realização somente pode ocorrer se as condições fáticas e jurídicas forem ideais, o que dificilmente ocorre nos casos difíceis. Isso porque, ainda que nos limitemos apenas às condições jurídicas, dificilmente a realização total de um princípio não encontrará barreiras na proteção de outros princípios ou de outros princípios. É justamente a essa possível colisão que Alexy quer fazer referência quando fala em 'condições jurídicas'. Como já se viu - e como se verá também a seguir -, no caso das regras a aplicação não depende de condições jurídicas do caso concreto, pelo menos não nesse sentido apontado. É dessa diferença de estrutura que decorrem as diferentes formas de aplicação das normas jurídicas: a subsunção e o sopesamento" (SILVA, Virgílio Afonso da. Op. cit., p. 46).

33 Em sentido idêntico: TAFFARELLO, Rogério Fernando. Triste tarde de fevereiro no Supremo Tribunal Federal, ou: "um requiém para a presunção de inocência". Boletim do Instituto Brasileiro de Direito Penal Econômico, Ano 04, edição especial. 2016, p. 08. Em sentido contrário, defendendo a presunção de inocência enquanto princípio: OLIVEIRA, Marlus Heriberto Arns de; MICHELOTTO, Mariana Nogueira. Presunção de inocência - avanço ou retrocesso? Boletim do Instituto Brasileiro de Direito Penal Econômico, Ano 04, edição especial. 2016, p. 11-12; LINHARES, Sólon Cícero. Presunção de inocência prevista no artigo $5^{\circ}$ LVII da Constituição Federal - Princípio ou Regra? É possível sua flexibilização? Boletim do Instituto Brasileiro de Direito Penal Econômico, Ano 04, edição especial. 2016, p. 02.

${ }^{34}$ Nesse sentido, é bastante elucidativa a definição de Daniel Wunder Hachem ao afirmar que a presunção de inocência é "Típico exemplo de norma com caráter de regra, no sentido de Ronald Dworkin: aplicável segundo a lógica 
Essa conclusão decorre não apenas de que ela deve ser aplicada integralmente até o marco normativo do trânsito em julgado, mas, igualmente, pelas previsões normativas regulamentadoras da quebra da presunção de inocência quanto à aplicação de penas, consoante preveem os artigos 105 e 147 da Lei de Execução Penal e do artigo 283 do Código de Processo Penal.

Inclusive, é este o entendimento expressado em decisão do Superior Tribunal de Justiça, em 14 de junho de 2017, ao determinar a impossibilidade de execução provisória de pena restritita de direitos ${ }^{35}$. Disso decorre o óbvio: se não vale para uma pena restritiva de direitos, tampouco vale para uma pena privativa de liberdade. Em ambos os casos, far-se-ia necessária a revogação ou a declaração de inconstitucionalidade dos dispositivos legais mencionados, inclusive, do próprio texto constitucional. Em outras palavras, a famosa regra do "tudo ou nada" (all-ornothing-fashion) de Ronald Dworkin ${ }^{36}$ é a que melhor explica a natureza jurídica da presunção de inocência, pois ela deve ser aplicada de forma plena até sua materialização em sentido contrário.

\section{O ESTADO DE INOCÊNCIA COMO gaRANTIA PROCESSUAL DECORRENTE DO PRINCÍPIO DA CULPABILIDADE}

O estado de inocência de todo cidadão é uma conquista que acompanha a evolução da formação dos Estados modernos como mecanismos de limitação do poderio punitivo estatal. Conforme preceitua Décio Franco David, a presunção de inocência pode ser compreendia como uma das

do tudo-ou-nada. No caso, a norma que fixa o prazo para recurso é válida e se aplica com tudo. Não há espaço para ponderação, diria Robert Alexy." (HACHEM, Daniel Wunder. Sepultamento da presunção de inocência pelo STF (e os funerais do Estado Democrático de Direito). Direito do Estado, n. 86, 2016. Disponível em: <http://www.direitodoestado.com.br/colunistas/ daniel-wunder-hachem/sepultamento-da-presuncao-de-inocencia-pelo-stf -e-os-funerais-do-estado-democratico-de-direito>. Acesso em 21 ago. 2017).

STJ. $3^{\text {a }}$ Seção. EREsp 1.619.087-SC, Rel. Min. Maria Thereza de Assis Moura, Rel. para acórdão Min. Jorge Mussi, julgado em 14/6/2017 (Info 609).

36 Cf. explicação do autor comparando as regras jurídicas às regras extralegais, em especial, com as regras de baseball: DWORKIN, Ronald. Taking Rights Seriously. Cambridge: Harvard University Press, 1977, p. 24.-25 
garantias derivadas do princípio da culpabilidade ${ }^{37}$. Essa fundamentação vinculada ao aludido princípio auxilia na compreensão da amplitude e aplicabilidade da referida garantia, além de expressar uma das balizas nas quais ocorre o entrecruzamento das esferas material e processual do sistema penal. Essas balizas de imbricação e orientação normativa/ interpretativa possuem uma finalidade de harmonizar o sistema, sempre em direção a um modelo democrático e constitucional.

A relação entre Direito penal material e Direito penal processual, conforme bem defende Paulo Queiroz, não deve ser apenas instrumental, mas material ${ }^{38}$; construindo, portanto, um verdadeiro sistema integrado, no qual os princípios incidam de modo unitário em ambas as esferas ${ }^{39}$. Paulo César Busato também corrobora esse entendimento, ao comparar as relações entre as esferas material e processual, afirma que:

O Direito penal só pode produzir uma classe de resultado: pena ou medida de segurança. Se esse é o único resultado produzido pelo Direito penal aplicado e ele é induvidosamente aflitivo dos demais direitos daquele que sofre sua interferência, o Processo deixa de ser um mero mecanismo de viabilização do Direito material penal para ocupar um lugar de equivalente protagonismo. É absolutamente inútil um Direito penal material cheio de garantias se o Processo penal admite, por exemplo, a tortura como meio de interrogatório. Desse modo, uma proposta de organização do Direito penal dentro de uma fórmula correspondente a um Estado social e democrático de Direito não pode abdicar de preocupações equivalentes no plano do Processo penal ${ }^{40}$.

Conforme asseverado acima, essa relação de unicidade/integralidade se apresenta de modo bastante firme quanto à culpabilidade, pois, na acertada afirmação de George Peter Fletcher, as normas materiais

37 DAVID, Décio Franco. Fundamentação principiológica do Direito Penal Econômico: um debate sobre a autonomia científica da tutela penal na seara econômica. 2014.263. Dissertação (Mestrado em Ciência Jurídica) - Universidade Estadual do Norte do Paraná, Jacarezinho, Paraná, p. 217 e ss.

BUSATO, Paulo César. Direito Penal: Parte Geral. 2. ed. São Paulo: Atlas, 2015, p. 983-984. 
estabelecem a culpa hipotética, em quanto as normas processuais determinam se um réu é culpado de fato ${ }^{41}$. Para o professor da Universidade de Columbia, a relação o juízo de culpabilidade se apresenta na relação integral por um silogismo legal de culpabilidade, de modo que o tipo penal em abstrato representa uma premissa maior, enquanto que os fatos dentro das regras processuais representam a premissa menor, de modo que a conclusão (culpado ou inocente) corresponde ao fechamento do silogismo ${ }^{42}$.

Quanto aos fundamentos de um sistema penal democrático e integrado, observa-se, com Juarez Cirino dos Santos, que o princípio da culpabilidade é o segundo instrumento mais importante de proteção individual no Estado de Direito, porque proíbe punir pessoas que não preenchem os requisitos do juízo de reprovação $0^{43}$. Em outras palavras, se não ocorrer confirmação do silogismo de culpa, conforme preceitua Fletcher, o Estado não poderá intervir na liberdade física dos cidadãos.

Assim, é verificável que o princípio da culpabilidade tem origem no reconhecimento do ser humano enquanto valor universal; suas raízes estão dispostas na filosofia cristã da Idade Média em razão do pensamento de respeito ao próximo ${ }^{44}$. Tradicionalmente atribui-se ao princípio um

41 FLETCHER, George Peter. Basic Concepts of Criminal Law. New York: Oxford University Press, 1998, p. 7.

42 FLETCHER, George Peter. Op. cit., p. 8.

43 SANTOS, Juarez Cirino dos. Direito Penal: Parte Geral. 2. ed. Rio de Janeiro: Lumen Juris/ICPC, 2007, p. 24.

44 BUSATO, Paulo César. Fundamentos para um Direito Penal Democrático. 4. ed. São Paulo: Atlas, 2013, p. 182-183. BRANDÃO, Claudio. Culpabilidade: sua análise na dogmática e no Direito Penal brasileiro. Ciências Penais, ano 1, n. 1. São Paulo: Revista dos Tribunais, set.-dez/2004, p. 171-174. Para este autor, a culpabilidade enquanto princípio só pode ser analisada sob a luz do método do Direito Penal, assim, utilizando-se da tópica, afirma: "O princípio da culpabilidade, que traduz a responsabilidade penal do homem, condiciona o método do direito penal porque é um dos mecanismos para o sopesamento do caso no processo da decisão e da argumentação jurídica, possibilitando a própria realização da tópica, que para garantir o respeito à dignidade humana pode superar o silogismo, assegurando, em determinados casos, decisões até mesmo contra legem. Quando se reconhecem, por exemplo, causas supralegais de inexigibilidade de conduta diversa, que é causa de exclusão da culpabilidade, reconhece-se a insuficiência do silogismo legal, que por óbvio não contempla tais causas, valorizando-se o homem pelo reconhecimento de circunstâncias concretas que devem afastar a aplicação do tipo penal. Isto é, 
triplo sentido: a) Fundamento da pena (imputabilidade, consciência da ilicitude e exigibilidade de conduta diversa); b) Graduação (elemento de determinação ou medição) de Pena; e, c) Fixação de dolo ou culpa (oposição à responsabilidade objetiva) ${ }^{45}$. Desse triplo sentido resultam três consequências: a) a culpabilidade é a medida da pena; b) a responsabilidade penal é pelo fato e não pelo autor; e, c) não há responsabilidade objetiva pelo simples resultado ${ }^{46}$.

Fernando Galvão, por sua vez, defende que a "garantia da culpabilidade exige a precisa identificação do objeto do juízo de valoração" ${ }^{47}$, motivo pelo qual, a culpabilidade "não pode ser conceito meramente formal e vazio de conteúdo, pois, caso contrário, o indivíduo submete-se ao incontrolável e imprevisível"48. Por esta razão, deve-se sempre levar em consideração que o princípio da culpabilidade está atrelado à "norma constitucional que proclama a dignidade da pessoa humana como um dos primeiros fundamentos da República (art. 1, III)”49. Eis, então, que as três consequências atreladas aos três sentidos apontados por Bitencourt devem ser ampliadas, resultando, atualmente, em cinco garantias ${ }^{50}:$ a) Responsabilidade pessoal (ou individual); b) Responsabilidade subjetiva ou culpabilidade em sentido estrito; c) Responsabilidade pelo fato; d) Presunção de inocência ou não consideração prévia de culpabilidade; e, e) Individualização da pena ${ }^{51}$.

pois, o uso da tópica para aumentar a liberdade, o que confirma que o homem é um ser reconhecido em sua dignidade no direito penal, sendo, no âmago, o próprio fim desse direito. (BRANDÃO, Claudio. Culpabilidade..., p. 178).

Por todos: BITENCOURT, Cezar Roberto. Tratado de Direito penal: Parte Geral, vol. 1. 9. ed. São Paulo: Saraiva, 2004, p. 14.

GALVÃO, Fernando. Direito Penal: Parte Geral. 5. ed. São Paulo: Saraiva, 2013, p. 141.

48 GALVÃO, Fernando. Op. cit., p. 141.

DOTTI, René Ariel. Curso de Direito Penal: Parte Geral. 3. ed. São Paulo: Revista dos Tribunais, 2010, p. 136.

50 Conforme DAVID, Décio Franco. Considerações sobre as garantias do princípio da culpabilidade no Direito Penal Econômico. In: CÂMARA, Luiz Antônio; FONTELLA, Bibiana. (Org.). Revista do Instituto Brasileiro de Direito Penal Econômico. Florianópolis: Empório do Direito, 2016, v. 1, p. 157-188; DAVID, Décio Franco. Delitos de Acumulação e proteção ambiental. Belo Horizonte: Editora D’Plácido, 2017, p. 227 e ss.

DAVID, Décio Franco. Fundamentação..., Op. cit., p. 209. 
Reitera-se, portanto que de acordo com a garantia da presunção de inocência ou não consideração prévia de culpabilidade, a culpabilidade se insere não apenas nos mecanismos de Direito material, mas é imprescindível à matéria processual ${ }^{52}$. Assim, não obstante esta garantia estar devidamente prevista no artigo $5^{\circ}$, inciso LVII, da Constituição, verifica-se norma de extrema importância ante a atuação penal estatal, cada vez mais influenciada aos mecanismos midiáticos ${ }^{53}$. Apenas a título elucidativo, podem ser utilizadas as expressões "presunção de inocência" e "presunção de não culpabilidade" como sinônimos; afinal, como bem pondera Gustavo Badaró, "as expressões 'inocente' e 'não culpável' constituem somente variantes semânticas de um idêntico conteúdo. É inútil e contraproducente a tentativa de apartar ambas as ideias" ${ }^{4}$. Por tal razão, podem ser usados ambos os termos para se referir à garantia.

Segundo Rogério Lauria Tucci, a presunção de inocência consiste na "asseguração, ao imputado, do direito de ser considerado inocente até

52 "O fato de que o princípio de culpabilidade seja fonte comum de outros princípios tanto na seara do direito material quanto do direito processual penal vem em reforço da idéia de comunhão de fontes entre o Direito penal e o Direito processual penal e em evidente rechace àqueles que preconizam a possibilidade de uma teoria geral do processo, capaz de abrigar sob um mesmo arcabouço principiológico o processo penal e o processo civil” (BUSATO, Paulo César. Fundamentos..., Op. cit., p. 205). Posicionamento idêntico em BUSATO, Paulo César. Direito Penal: Op. cit., p. 39, rodapé 69. Sobre uma teoria autônoma do Direito Processual Penal frente ao Direito processual Civil: COUTINHO, Jacinto Nelson de Miranda. A lide e o conteúdo do processo penal. Curitiba: Juruá, 1989, p. 129 e ss.

53 Sobre o assunto, urge transcrever um trecho de um julgado do Supremo Tribunal Federal: "Não se desconhece que programas jornalísticos sensacionalistas infestam o cotidiano, influenciando de maneira sórdida a percepção e o raciocínio do cidadão, substituindo o resguardo do direito constitucional à informação por deturpação de fatos e versões. O "gosto de sangue" parece ser o mote principal desses veículos, que desconhecem respeito por vidas inocentes e honra alheia, em nome da necessidade de clientela e audiência, que, em substância, se reduzem a busca de mercado e, pois, de lucro sem compromisso ético" (HC 111756 MC, Relator(a): Min. Ricardo Lewandowski, julgado em 22/12/2011, publicado em processo eletrônico DJe-022 divulg 31/01/2012 public 01/02/2012).

54 BADARÓ, Gustavo Henrique. Processo Penal. 3. ed. São Paulo: Revista dos Tribunais, 2015, p. 57. 
que sentença penal condenatória venha transitar formalmente em julgado, sobrevindo, então a coisa julgada de autoridade relativa" ${ }^{55}$.

Assim, a garantia de que será mantido o estado de inocência até o trânsito em julgado da sentença condenatória provoca consequências diretas na forma de tratamento para com o réu, no ônus da prova e na "obrigatoriedade de que a constatação do delito e a aplicação da pena serão por meio de um processo com todas as garantias e através de uma sentença fundamentada (motivação como instrumento de controle da racionalidade)" ${ }^{56}$.

Acerca do tratamento para com o réu, destaca Aury Lopes Jr que a presunção deve ser um princípio da maior relevância, pois ele obriga o juiz "não só a manter uma posição "negativa" (não o considerando culpado), mas sim a ter uma postura positiva (tratando-o efetivamente como inocente)" ${ }^{57}$. Afirma ainda que a presunção de inocência

a) Predetermina a adoção da verdade processual, relativa, mas dotada de um bom nível de certeza prática, eis que obtida segundo determinadas condições.

b) Como consequência, a obtenção de tal verdade determina um tipo de processo, orientado pelo sistema acusatório, que impõe a estrutura dialética e mantém o juiz em estado de alheamento (rechaço à figura do juiz-inquisidor - com poderes investigatórios/ instrutórios - e consagração do juiz de garantias ou garantidor).

c) Dentro do processo, traduz-se em regras para o julgamento, orientando a decisão judicial sobre os fatos (carga da prova).

d) Traduz-se, por último, em regras de tratamento do acusado, posto que a intervenção do processo penal se dá sobre um inocente. ${ }^{58}$

55 TUCCI, Rogério Lauria. Direitos e garantias individuais no processo penal brasileiro. 3. ed. São Paulo: Revista dos Tribunais, p. 313.

56 LOPES JUNIOR, Aury. Introdução Crítica ao Processo Penal: fundamentos da instrumentalidade constitucional. 5. ed. Rio de Janeiro: Lumen Juris, 2010, p. 176.

57 LOPES JUNIOR, Aury. Direito Processual Penal. 11. ed., São Paulo: Saraiva, 2014, p. 218.

58 LOPES JUNIOR, Aury. Direito processual penal e sua conformidade constitucional. 8. ed. Rio de Janeiro: Lumen Juris, 2011, p. 179. A mesma passagem 
Por tal motivo, é possível afirmar que essa garantia, formadora de um processo penal liberal, se impõe como um verdadeiro dever de tratamento, atuando tanto na dimensão interna do processo quanto na externa ${ }^{59}$.

Em sua dimensão interna, impõe um dever de tratamento ao juiz, no sentido de repassar todo o ônus probatório à acusação e que a dúvida seja uma baliza absolutória, ao mesmo tempo em que o uso de prisões cautelares não se dê de modo abusivo ${ }^{60}$. Na dimensão externa, "a presunção de inocência exige uma proteção contra a publicidade abusiva e a estigmatização (precoce) do réu" ${ }^{61}$, sua consequência lógica é que o "bizarro espetáculo montado pelo julgamento midiático deve ser coibido pela eficácia da presunção de inocência” ${ }^{2}$. Em síntese, a garantia da não presunção de culpabilidade afeta diretamente o ônus probatório, a limitação da publicidade sobre o réu e o processo e a vedação ao uso abusivo de prisões cautelares ${ }^{63}$.

Gustavo Badaró, ao comentar o conteúdo da garantia, afirma que o estado de inocência possui três significados ${ }^{64}$. Primeiramente,

consta em LOPES JR., Aury; GLOECKNER, Ricardo Jacobsen. Investigação preliminar no processo penal. 6. ed. São Paulo: Saraiva, 2014, p. 71.

LOPES JUNIOR, Aury. Direito Processual Penal. Op. cit., p. 220; LOPES JUNIOR, Aury. Direito processual penal e sua conformidade constitucional. Op. cit., p. 181. LOPES JUNIOR, Aury. Direito Processual e sua conformidade constitucional. Op. cit., p. 181.

${ }^{61}$ LOPES JUNIOR, Aury. Direito Processual e sua conformidade constitucional. Loc. cit.

62 LOPES JUNIOR, Aury. Direito Processual e sua conformidade constitucional. Loc. cit. Nesse sentido, Claus Roxin afirma que a imagem do acusado deve sempre ser preservada, pois integra o campo dos direitos personalíssimos, cf. ROXIN, Claus. Derecho Procesal Penal. Buenos Aires: Editores Del Puerto, 2003, 127-128.

63 LOPES JUNIOR, Aury. Direito Processual Penal. Op. cit., p. 220. Alberto Binder afirma que a presunção de não-culpabilidade mostra que "'ninguém é culpado se uma sentença não o declara assim'. Isto, de fato, significa: 1. Que somente a sentença tem essa faculdade. 2. Que no momento da sentença existem duas possibilidades: culpado ou inocente. Não existe uma terceira possibilidade. 3. Que a 'culpabilidade' deve ser juridicamente provada. 4. Que essa construção implica a aquisição de um grau de certeza. 5. Que o acusado não tem que provar sua inocência. 6. Que o acusado não pode ser tratado como um culpado. 7. Que não podem existir mitos de culpa, isto é, partes da culpa que não precisam ser provadas" (BINDER, Alberto M. Introdução ao Direito Processual Penal. Rio de Janeiro: Lumen Juris, 2003, p. 87).

64 BADARÓ, Gustavo Henrique. Op. cit., p. 57. 
uma faceta de garantia política correspondente à adoção de um processo acusatório, no qual, o in dubio pro reo se torna um consectário necessário. Em segundo lugar, é uma regra de tratamento do acusado "a ser utilizada sempre que houver dúvida sobre fato relevante para a decisão do processo" "65. A terceira repercussão expressa uma regra de tratamento do acusado, impondo limites às prisões cautelares e à execução provisória ou antecipada da pena ${ }^{66}$.

Especificamente quanto a impor uma regra de tratamento, percebe-se uma harmonização com a proposta de Luigi Ferrajoli, para quem a presunção de inocência deriva do princípio de submissão à jurisdiçãa ${ }^{67}$. O princípio de submissão à jurisdição exige que não haja culpa sem juízo e que não haja juízo sem que a imputação acusatória se sujeita à provação e uma possível refutação ${ }^{68}$. Assim, por tal princípio, Ferrajoli defende a presunção de inocência do imputado até prova contrária decretada pela sentença definitiva de condenação ${ }^{69}$. Essa perspectiva garantista reforça a proposta aqui defendida de que a garantia do estado de inocência (ou presunção de não-culpabilidade) é um efeito direto do princípio da culpabilidade, a qual só é afastada no caso concreto (premissa menor do silogismo proposto por Fletcher) com o trânsito em julgado de uma sentença condenatória, ou seja, com a formação de coisa julgada. A coisa julgada torna os efeitos da sentença imutáveis, produzindo imutabilidade de acordo com suas duas naturezas (formal e material).

A coisa julgada formal corresponde à imutabilidade da sentença no próprio processo, a qual ocorre pela preclusão das vias impugnativas sendo que tal faceta da coisa julgada se aplica a todas as formas de sentença, inclusive a terminativa ${ }^{70}$. Por sua vez, a coisa julgada material equivale à imutabilidade dos efeitos da sentença, sendo aplicada, apenas, às decisões

65 BADARÓ, Gustavo Henrique. Loc. cit.

66 BADARÓ, Gustavo Henrique. Op. cit., p. 58.

67 FERRAJOLI, Luigi. Direito e Razão: Teoria do Garantismo Penal. 3. ed. São Paulo: Revista dos Tribunais, 2010, p. 505.

68 FERRAJOLI, Luigi. Loc. cit.

69 FERRAJOLI, Luigi. Loc. cit.

70 BADARÓ, Gustavo Henrique. Op. cit, p. 547. 
de mérito, as quais projetam seus efeitos para fora do processo ${ }^{71}$. Com isso, "formada a coisa julgada material, o objeto do processo não poderá voltar a ser discutido em outro processo envolvendo as mesmas partes: é o que se denomina função negativa da coisa julgada"72.

Observa-se com tais conceitos que com a determinação do texto constitucional de que a presunção de inocência produz efeitos até o trânsito em julgado de sentença condenatória, o que se está afirmando é que sem ocorrer coisa julgada material não é possível afastar tal presunção! O mesmo raciocínio pode ser extraído das regras constantes nos já mencionados artigos 105 e 147 da LEP e 283 do CPP.

Em sentido contrário ao aqui defendido, advogando a possibilidade de execução antecipada da pena pela flexibilização da regra da presunção de inocência, Américo Bedê Júnior e Gustavo Senna afirmam que não deve prevalecer uma presunção de inocência diante de uma sentença condenatória que "analisou a fundo as questões e circunstâncias do caso concreto"73. Igualmente, destacam o fato de que recursos para o STF e o STJ não possuem efeito suspensivo ${ }^{74}$. No entanto, esse segundo argumento é facilmente refutado pelo artigo 1.029, $\$ 5^{\circ}$ do Código de Processo Civil de 2015, que prevê o efeito suspensivo para ambos os recursos. Quanto ao primeiro argumento (sem sequer tratar do desrespeito ao duplo grau de jurisdição), os autores distorcem não apenas o conceito de coisa julgada e trânsito em julgado, como também demonstram fé em um julgamento isento de parcialidades extraprocessuais submissas às mais variáveis desconfianças que se podem ter quando o processo penal se propõe a satisfazer o atual anseio popular de alcançar pacificação social pelo processo penal. De acordo com a certeira explicação de Rubens Casara, a obtenção de pacificação social pelo processo penal é um mito que serve apenas aos movimentos repressistas e a uma violenta e opressora política criminal de "gestão da pobreza", servindo, consequentemente,

\footnotetext{
71 BADARÓ, Gustavo Henrique. Loc. cit.

72 BADARÓ, Gustavo Henrique. Op. cit, p. 548.

73 BEDÊ JÚNIOR, Américo; SENNA, Gustavo. Princípios do Processo Penal: entre o garantismo e a efetividade da sanção. São Paulo: Revista dos Tribunais, 2009, p. 84.

74 BEDÊ JÚNIOR, Américo; SENNA, Gustavo. Op. cit., p. 85.
} 
ao desmonte das políticas sociais cidadãs e democráticas, conforme tem ocorrido em inúmeros casos concretos ${ }^{75}$.

Desta forma, o entendimento esboçado no $\mathrm{HC} \mathrm{n}^{\circ} 84.078 / \mathrm{MG}$ é o que melhor se coaduna com a garantia de inocência, a qual é uma regra que deve ser aplicada a todo processo penal de modo que a execução da pena só pode ser iniciada após o trânsito em julgado da sentença condenatória.

Nesse sentido, válido transcrever as palavras do Ministro Eros Grau ao julgar o alusivo writ: "Apenas um desafeto da Constituição admitiria que alguém fique sujeito a execução antecipada da pena de que se trate. Apenas um desafeto da Constituição" 76 . Defender o cumprimento antecipado da pena corresponde a subtrair do réu sua condição de sujeito processual, convertendo-o em um objeto do processo ${ }^{77}$.

A aplicabilidade de sanção antes do trânsito em julgado da sentença condenatória foi objeto de análise da Corte Interamericana de Direitos Humanos no caso "Ricardo Canese vs. Paraguai", decidido em 2004. No referido caso, Ricardo Nicolás Canese Krivoshein teve o reconhecimento da lesão aos seus direitos humanos por ficar proibido de sair do país por um período de quase oito anos por ter praticado o delito de difamação

75 CASARA, Rubens R. R. Mitologia Processual Penal. São Paulo: Saraiva, 2015, p. 194-197.

76 No mesmo sentido, Amilton Bueno de Carvalho afirma que: "salvar o futuro do direito é salvar o futuro da democracia, são as duas caras de uma mesma moeda: no momento que se joga fora o direito, joga fora a democracia; quando se joga fora a democracia, se joga fora o direito; só há democracia sustentada pelo direito, só há direito dentro da democracia (um sistema legal construído fora da democracia não é direito) e o critério legitimador interno do direito, no plano de sua verticalidade, é a Constituição. Daí porque o juiz deve estar vinculado à lei, mas não a qualquer lei - somente deve obediência àquelas que fazem presentes os valores materiais previstos na Constituição ou em princípios inegociáveis. Para ele, o direito, então, é sistema de proteção do débil; ambiciona-se um Estado social máximo e um Estado punitivo mínimo; um maior bem-estar ao não desviante e o menor sofrimento possível ao desviante - a quem se deve permitir o gozo de direitos, embora com alguma limitação; existem princípios que nem a unanimidade pode revogar: são a proteção do um contra todos” (CARVALHO, Amilton Bueno. Direito Penal a marteladas: Algo sobre Nietzsche e o Direito. Rio de Janeiro: Lumen Juris, 2013, p. 46-47).

77 Sobre a diferenciação entre sujeito do processo e objeto do processo: ROXIN, Claus. Op. cit., p. 123 e ss. 
contra seu concorrente à presidência do Paraguai Juan Carlos Wasmosy. Embora Canese tenha sido absolvido em 2002 pela Corte Suprema de Justiça do Paraguai, ele havia sido condenado em primeiro grau, motivo pelo qual teve seu direito de sair do país restringido. A CIDH reconheceu na sentença que a restrição ao direito de ir e vir equivaleu à antecipação da execução da pena, o que violou a presunção de inocência ${ }^{78}$.

Corroborando o entendimento aqui exposto, Estefânia Maria de Queiroz Barbosa e Guilherme Brenner Lucchesi afirmam que a decisão do STF permite duas interpretações: a) "ou passamos a entender que a prisão de alguém baseada em sua culpa não significa considerá-lo culpado, torcendo a lógica e executando pena restritiva de liberdade em relação a pessoas inocentes" 79 , o que por si só, seria um absurdo sem precedentes dentro do ordenamento ou b) "admitimos que o texto de uma cláusula pétrea constitucional pode ser totalmente desconsiderado, abrindo perigoso precedente para futuras infrações à ordem constitucional" ${ }^{\text {, }}$, o que geraria uma insegurança jurídica sem limites.

Ante o exposto, desde já é possível concluir que a postura apresentada pelo STF ao decidir o HC 126.292/SP fere a garantia do estado de inocência, motivo pelo qual deve ser modificado, retornando-se ao posicionamento anteriormente exposto no $\mathrm{HC} 84.078 / \mathrm{MG}^{81}$.

78 Conforme item 162 do capítulo 3.2 da sentença (disponível em: <http://www. corteidh.or.cr/CF/jurisprudencia2/ficha_tecnica.cfm?nId_Ficha=218>. Acesso em 21 ago. 2017). Maiores declinações sobre o processo podem ser encontradas em GIACOMOLLI, Nereu José. O devido processo penal: abordagem conforme a Constituição Federal e o Pacto de São José da Costa Rica. São Paulo: Atlas, 2014, p. 105 e ss.

79 BARBOSA, Estefânia Maria de Queiroz; LUCCHESI, Guilherme Brenner. A interpretação inconstitucional do STF no HC 126.292. Boletim do Instituto Brasileiro de Direito Penal Econômico, Ano 04, edição especial. 2016, p. 07.

80 BARBOSA, Estefânia Maria de Queiroz; LUCCHESI, Guilherme Brenner. Loc. cit.

81 No mesmo sentido, OLIVEIRA, Marlus Heriberto Arns de; MICHELOTTO, Mariana Nogueira. Loc. cit. Sobre essa afirmação, é merecedor de transcrição um trecho do voto do Ministro Marco Aurélio Mello no HC em comento: "Reconheço que a época é de crise maior, mas justamente nessa quadra de crise maior é que devem ser guardados parâmetros, princípios, devem ser guardados valores, não se gerando instabilidade porque a sociedade não pode viver aos sobressaltos, sendo surpreendia. Ontem, o Supremo disse que não poderia haver execução provisória, em jogo, a liberdade de ir e vir. Hoje, pode". 


\section{ANTECIPAÇão EXECUÇão dA PENA: UM RETORNo Às teorias ABSOLUTAS DA PENA E A DETURPAÇÃO DO SISTEMA PENAL INTEGRADO}

Além da infração ao estado de inocência, apura-se que no julgamento do HC 126.292/SP foram utilizados argumentos retóricos para comprovar e fundamentar uma postura previamente adotada, tais como a necessidade de superar o paradigma da prescrição pela demora de execução da pena e a contenção de recursos protelatórios, ambos os pontos, segundo os ministros, seriam geradores de impunidade.

Como bem salienta Amilton Bueno de Carvalho, o discurso de impunidade é uma crença generalizada, e por ser crença, "depende unicamente da fé (justifica-se por si-mesmo): não interessa saber se é verdade ou não, se isso está comprovado ou não - a fé indica que é e pronto, é-porque-é!" 82 . Essa crença generalizada se verifica, por exemplo, no trabalho de Sólon Cícero Linhares, segundo o qual o STF teria dado uma resposta à sociedade por confrontar a impunidade ${ }^{83}$. Entretanto essa argumentação está pautada em uma atuação simbólica ${ }^{84}$ do Direito penal e acaba por renovar as teorias absolutas da pena.

Segundo a visão retributiva, a pena corresponde a "uma compensação de culpa, uma resposta estatal ao mal cometido, de modo a restabelecer a ordem dos valores, tais como devem ser" ${ }^{\prime 5}$. Em outras palavras, para essa teoria "o fundamento que justifica o castigo radica em que este é a justa retribuição da violação do direito cometida pelo delinquente" ${ }^{86}$. Por isso, para aqueles que defendem tal teoria, a pena "não vislumbra nenhum fim socialmente útil, postulando a resposta, a expiação do mal cometido, traduzido juridicamente por um injusto

82 CARVALHO, Amilton Bueno de. Op. cit., p. 81.

83 LINHERES, Sólon Cícero. Op. cit., p. 03.

84 Sobre o uso inadequado do simbolismo: DAVID, Décio Franco. Simbolismo: o hambúrguer do marketing político-criminal. Escola Superior de Direito Público. Disponível em: <http://esdp.net.br/simbolismo-o-hamburguer-do-marketing-politico-criminal/>. Acesso em 03 mar. 2017.

85 SALVADOR NETTO, Alamiro Velludo. Finalidades da Pena: Conceito material de delito e sistema penal integral. São Paulo: Quartier Latin, 2009, p. 205.

86 BOZZA, Fábio da Silva. Teorias da Pena: Do discurso jurídico à crítica criminológica. Rio de Janeiro: Lumen Juris, 2013, p. 07. 
culpável" ${ }^{87}$. Em suma, para o retribucionismo a pena é um mal que objetiva a contraposição de outro mal correspondente ao crime ${ }^{88}$.

Os dois principais autores desse modelo teórico foram Immanuel Kant e Georg Wilhelm Friedrich Hegel, expoentes máximos da filosofia idealista alemã, sendo que ambos os autores trabalharam com a ideia de retribuição do mal pela pena. A diferença entre suas propostas é que Kant se fundamentou em argumentos éticos e morais, enquanto que Hegel trabalhou com uma fundamentação de base jurídica ${ }^{89}$.

Embora ambas as propostas tenham resultado em acertos dogmáticos como a ideia de proporcionalidade da punição diante do crime realizado e de responsabilização pautada na culpabilidade individual do sujeito ${ }^{90}$, certamente, as críticas a elas atribuídas preponderam. Afinal, a proposta do Direito penal de exercer o controle social pela proteção de bens jurídicos não é compatível com a "simples" punição ou retribuição do mal. Do mesmo modo, a teoria kantiana pode resultar em um Estado déspota, o que proporciona, igualmente, a formalização de uma justiça meramente punitiva, que "não leva em consideração o homem como um ser social, em convivência com outros homens" "91, bastando recordar do famoso exemplo da "ilha" ${ }^{2}$. Ainda, a crítica que merece maior mérito possui bases político-criminais. Observe-se que a realidade latino-americana impede o uso da proposta retribucionista haja vista que esse se "baseia no pressuposto da existência prévia de uma igualdade social”93, a qual é uma falácia

87 SALVADOR NETTO, Alamiro Velludo. Op. cit., p. 206.

BUSATO, Paulo César. Direito Penal. Op. cit., p. 749.

Sobre as bases epistemológicas de seus pensamentos: SANTOS, Juarez Cirino. Op. cit., p. 456; BUSATO, Paulo César. Direito Penal. Op. cit., p. 751-752.

BUSATO, Paulo César. Fundamentos do Direito penal brasileiro. 3. ed. Curitiba: Edição do Autor, 2012, p. 309.

91 FERRÉ OLIVÉ, Juan Carlos; NÚNEZ PAZ, Miguel Ángel; OLIVEIRA, Willian Terra de; BRITO, Alexis Couto de. Direito Penal Brasileiro: Princípios fundamentais e sistema. São Paulo: Revista dos Tribunais, 2011, p. 194.

92 FERRÉ OLIVÉ, Juan Carlos; NÚNEZ PAZ, Miguel Ángel; OLIVEIRA, Willian Terra de; BRITO, Alexis Couto de. Loc. cit.

93 BUSATO, Paulo César. Fundamentos do Direito penal brasileiro. Op. cit., p. 312. 
nos estados latino-americanos, principalmente diante do vertiginoso uso midiático do processo penal ${ }^{94}$.

Porém, embora tais críticas sejam bastante contundentes, não é tão simples assim superar os paradigmas retribucionistas (sejam eles de vertente kantiana ${ }^{95}$ ou hegeliana ${ }^{96}$ ). Principalmente, pelo fato de que a psicologia popular e a necessidade de superação do "paradigma" da impunidade constroem uma nova base antropológica para a pena retributiva ${ }^{97}$. Esse imaginário coletivo influenciado pelo forte papel desempenhado pela mídia que, "sem contraditório, ampla defesa ou presunção de inocência, já fornece os culpados, antes mesmo da instrução criminal"98, materializam as medidas que John Pratt ${ }^{99} \mathrm{e}$ Simon Hallsworth ${ }^{100}$ definem como punição pós-moderna. Segundo Hallsworth, as "fontes das quais a punição pós-moderna deriva tem suas raízes não somente na lógica da ordem penal pré-moderna, mas

94 "A influência da televisão (e das corporações midiáticas que a exploram) no funcionamento concreto do sistema de justiça explica, em grande parte, o processo de dessimbolização (do desaparecimento dos limites constitucionais, por exemplo) que faz com que os direitos e garantias fundamentais passem a ser tratados como mercadorias, portanto negociáveis" (CASARA, Rubens R. R. Processo Penal do Espetáculo (e outros ensaios). 2. ed. Florianópolis: Tirant lo Blanch, 2018, p. 13).

95 Sobre a dificuldade de superar a matriz kantiana: GRECO, Luís. A ilha de Kant. In: GRECO, Luís; MARTINS, António Carvalho. Direito penal como crítica da pena: estudos em homenagem a Juarez Tavares por seu $70^{\circ}$ aniversário em 2 de setembro de 2012. Madrid: Marcial Pons, 2012, p. 263-279.

Sobre a dificuldade de superar a matriz hegeliana: DAVID, Décio Franco; SALOMAO NETO, Antônio. Reflexões sobre a pena em Hegel. VI Simpósio Internacional de Análise Crítica do Direito, 2017, Jacarezinho. Anais do VI Simpósio Internacional de Análise Crítica do Direito. Jacarezinho: UENP, 2016, p. 120-137.

97 No mesmo sentido: SANTOS, Juarez Cirino dos. Op. cit., p, 456; BOZZA, Fábio da Silva. Op. cit., p. 09.

98 CASARA, Rubens R. R. Processo Penal do Espetáculo. Op. cit., p. 13.

99 PRATT, John. O retorno dos "homens carrinho de mão" ou a chegada da punição pós-moderna? In: CÂNEDO, Carlos; FONSECA, David S (Org.). Ambivalência, contradição e volatilidade no sistema penal. Belo Horizonte: Editora UFMG, 2012, p. 128-160.

${ }^{100}$ HALLSWORTH, Simon. A questão de uma punição pós-moderna. In: CÂNEDO, Carlos; FONSECA, David S (Org.). Ambivalência, contradição e volatilidade no sistema penal. Belo Horizonte: Editora UFMG, 2012, p. 185-209. 
especificamente na economia penal de excesso a qual ela estava vinculada" ${ }^{101}$, possibilitando que clamor punitivo popular - sem qualquer senso racional crítico - migre da execução da pena para as garantias processuais, em uma verdadeira antecipação de barreiras de imputação do sistema de justiça criminal, destruindo por completo os anseios que a modernidade projetou para Estados com sistemas democráticos ${ }^{102}$. Essa nova base configura o que David e Salomão Neto caracterizam como fetichismo penal ${ }^{103}$. Isso ocorre porque o discurso punitivista se concentra na antecipação do seu objeto de desejo (gozo), trazendo a punição para dentro do campo processual. Dessa forma, a pena passa a ser um "objeto", não importando o que é desejado, mas, sim, o motivo sublime do desejo (visualização da punição): A pena é desejada como espetáculo e o espetáculo não pode atrasar! Assim ela propicia uma sensação de satisfação ${ }^{104}$ e, psicanaliticamente, um gozo rápido. Nas palavras dos autores:

A essência da pena, seus horrores e a condição sob a qual ela submete o criminoso são abandonadas pela perspectiva fetichista. $\mathrm{O}$ que realmente importa é: "ele fez errado, tem de pagar". Com isso, há uma espécie de idealização, na melhor forma de transubstanciação de valores, na qual a pena é esse instrumento mágico e santo de gozo. Ela submete o homem não a sua perda de subjetividade, como nos campos de concentração nazistas, nem ao criminoso que confessa como nos gulags soviéticos (ZIZEK, 2013, p. 66), mas sim ao milagre da ressocialização.

${ }^{101}$ HALLSWORTH, Simon. Op. cit., p. 206.

102 Em sentido próximo, Alexandre Morais da Rosa afirma que na atual conjectura penal, o mecanismo sancionador serve para manter as regras de interesse do mercado, motivo pelo qual há que se punir alguém (objetos) para que o sistema se mantenha (Cf. ROSA, Alexandre Morais da; CARVALHO, Thiago Fabres de. Processo penal eficiente e ética da vingança: em busca de uma criminologia da não violência. Rio de Janeiro: Lumen Juris, 2011, p. 71-73.

${ }^{103}$ DAVID, Décio Franco; SALOMÃO NETO, Antônio. Fetichismo e Pena. Op. cit., p. 10 e ss.

${ }^{104}$ O marcante capítulo inicial de Vigiar e Punir de Foucault com a descrição da execução de Damiens é um perfeito exemplo do espetáculo que circunda a pena (FOUCAULT, Michel. Vigiar e Punir: Nascimento da Prisão. 36. ed. Petrópolis: Vozes, 2009, p. 9 e ss). 
O discurso da impunidade reforça esse fetiche pois, por meio dele, a pena é desejada enquanto instrumento de conversão de criminosos em "homens de bem" ${ }^{105}$, ainda no curso processual. O problema de tal perspectiva é que, em estrita semelhança com o sujeito fetichista de Sigmund Freud ${ }^{106}$, é sabido tampouco a pena em si tem esse poder mágico, quanto mais o processo penal. Pelo contrário!

Nesse enfoque crítico psicanalítico, a antecipação da execução da pena pode ser atribuída à necessidade de um gozo rápido, a mera satisfação do fetiche por um pseudoprazer em razão do sofrimento corporal alheio ${ }^{107}$. Afinal, é impossível dissociar a ideia de punição (prisão) de penas corpóreas ${ }^{108}$.

Não obstante tais constatações, verifica-se que a ânsia punitivista ainda proporciona outros argumentos aos ministros do STF. Em especial, depreende-se de seus votos que o cerne da discussão foi redundante quanto ao efeito suspensivo dos recursos Especial e Extraordinário. No entanto, o verdadeiro problema não está alocado, apenas, em aspectos procedimentais, mas, fundamentalmente, quanto à permanência de respeito de uma regra constitucional e sua eficácia de norma constitucional que se materializa de forma integrada (planos material e processual).

Além disso, durante o julgamento do HC 126.292/SP foram realizadas menções ao Direito constitucional comparado como mero

${ }^{105}$ Eis aqui a definição das Tarântulas de Friedrich Nietzsche: "Assim, entretanto, aconselho-vos, meus amigos: desconfiai de todo aquele no qual o impulso de castigar é poderoso! São pessoas de má raça e de má linhagem; de seus semblantes espreitam o carrasco e o perseguidor. Desconfiai de todos aqueles que falam muito de sua justiça! Em verdade, em suas almas não é só o mel que lhes falta. E quando se intitulam "bons e justos", não vos esqueceis de que não falta nada para torná-los fariseus, exceto - poder” (NIETZCHE, 2014, p. 136).

${ }^{106}$ Sobre o fetichismo para Freud: FREUD, Sigmund. Obras Completas, volume 17: Inibição, sintoma e angústia, O futuro de uma ilusão e outros textos (19261929). São Paulo: Companhia das Letras, 2014, p. 303 e ss; DAVID, Décio Franco; SALOMÃO NETO, Antônio. Fetichismo e Pena. Op. cit., p.06 e ss.

107 Acerca da aplicação de uma punição fetichista em casos concretos: SMANIOTTO, Joao Vitor Passuello; DAVID, Décio Franco. Parcialidade e fetiche: Freud Explica. In: PRONER, Carol et. al. (Org.). Comentários a uma sentença anunciada: o processo Lula. Bauru: Canal 6 Editora, 2017, p. 224-230.

${ }^{108}$ COSTA, José de Faria. Linhas de direito penal e de filosofia: alguns cruzamentos reflexivos. Coimbra: Coimbra editora, 2005, p. 87 e ss. 
argumento de autoridade ${ }^{109}$ para fundamentar a decisão tomada ${ }^{110}$. Como bem anotam Barbosa e Lucchesi, trazendo o estudo feito por membros do Ministério Público Federal sobre o tema ${ }^{111}$, o Ministro relator, em seu voto, alega que "em nenhum país do mundo, depois de observado o duplo grau de jurisdição, a execução de uma condenação fica suspensa, aguardando referendo da Corte Suprema”.

Aqui, mais uma vez, apura-se um erro na fundamentação da decisão, afinal, "o uso do direito constitucional comparado deve ser feito com método, sendo necessário enfrentar i) o contexto sócio-político no qual juízes de outros cortes decidiram e ii) o ordenamento jurídicoconstitucional de cada país" 112 e não como indicação apenas de que em ordenamentos estrangeiros a regra é essa ou aquela.

Assim, resta evidenciado o desacerto da decisão tomada pelo STF no julgamento, necessitando-se, com urgência o retorno ao entendimento anterior, apresentado no $\mathrm{HC} \mathrm{n}^{\circ}$ 84.078/MG. Somente assim, estará sendo cumprida a garantia de presunção de inocência e o respeito ao conceito de trânsito em julgado.

\section{ConsideraçõEs finaIS}

Conforme argumentos apresentados acima e reforçando que a decisão do STF se vincula ao senso comum, o qual é demasiadamente agressivo, exigindo "punir cada vez mais e cada vez mais a penas longas e cada vez mais com menos benefícios no momento da execução penal" ${ }^{113}$,

\footnotetext{
109 "Nesse tipo de argumentação, a pessoa que toma a decisão e a decisão em si mesma são mais importantes do que o raciocínio desenvolvido para se chegar nela. Ao argumentar, a pessoa da autoridade expõe os motivos pelos quais foi convencida de determinada solução jurídica. (...) De qualquer forma, o objetivo da autoridade não é, nesse registro, argumentar em nome da melhor solução possível para o caso, mas sim apresentar as razões pelas quais formou sua opinião pessoal sobre qual deva ser a melhor solução para o caso" (RODRIGUEZ, José Rodrigo. Como decidem as cortes? Para uma crítica do Direito (brasileiro). São Paulo: FGV Editora, 2013, p. 73-74, itálicos no original).

110 BARBOSA, Estefânia Maria de Queiroz; LUCCHESI, Guilherme Brenner. Loc. cit.

${ }^{111}$ BARBOSA, Estefânia Maria de Queiroz; LUCCHESI, Guilherme Brenner. Loc. cit.

112 BARBOSA, Estefânia Maria de Queiroz; LUCCHESI, Guilherme Brenner. Loc. cit.

113 CARVALHO, Amilton Bueno de. Op. cit., p. 81.
} 
pode-se concluir, em resposta às duas indagações que nortearam o presente artigo ${ }^{114}$, que:

1. A presunção de inocência não detém conteúdo normativo suficiente para ser considerado um princípio, embora, não raras vezes, seja assim chamado pela doutrina e jurisprudência. Em verdade, apurase que a densidade normativa da presunção de inocência corresponde a uma norma regra, pois não admite a ductilidade atribuída aos comandos normativos principiológicos. Pelo contrário, apresenta-se como uma regra que deve ser válida exatamente para aquilo que ela exige.

2. A garantia do estado de inocência (ou presunção) é derivada do princípio da culpabilidade. Sua previsão no artigo $5^{\circ}$, inciso LVII da Constituição apenas reforça seu status de garantia individual de todo processado criminalmente. Disso decorre que o magistrado, ao analisar o caso, deve manter uma posição negativa de não considerar o réu culpado ao tempo que exerce uma postura positiva, tratando-o efetivamente como inocente. Por isso a execução da pena só pode ser iniciada após o trânsito em julgado da sentença condenatória (coisa julgada formal e material). Defender o cumprimento antecipado da pena corresponde a subtrair do réu sua condição de sujeito processual, convertendo-o em um objeto do processo (a objetivação do sujeito corresponde às razões das teorias absolutas da pena, daí sua conexão em um sistema penal integrado)..

3. A utilização de argumentos de autoridade pelos termos "impunidade", "recursos protelatórios" e "comparação com ordenamentos estrangeiros" apenas reitera a base epistemológica de teorias absolutas da pena; segundo as quais, a sanção tem caráter meramente retributivo, o que resulta em uma ampliação fetichista pautada no mito da pacificação social pelo processo penal.

4. A compreensão da presunção de inocência enquanto norma regra implica na aplicação integral (aspectos materiais e processuais) de seu conteúdo, o que enseja em reconhecer a ela uma garantia de proteção do "um contra todos", conforme preconiza Amilton Bueno de Carvalho. O jogo democrático das garantias constitucionais não permite

114 "1) a execução antecipada de pena pode mudar os conceitos de coisa julgada e presunção de inocência?; 2) a execução antecipada de pena corresponde ao retorno das teorias absolutas da pena?" 
a relativização de uma norma evidente e que já detinha interpretação coadunada com o texto constitucional. Um sistema penal integrado deve manter suas premissas cidadãs e democráticas intactas e harmoniosas à fundamentação principiológica, de modo que a execução antecipada da pena desrespeita não apenas mecanismos de tratamento processual, mas infringe diretamente o conceito de coisa julgada, a regra da presunção de inocência (derivada do princípio da culpabilidade enquanto garantia de presunção de não-culpabilidade) e institui um sistema no qual a pena se justifique em si mesma (característica central das teorias absolutas da pena).

\section{REFERÊNCIAS BIBLIOGRÁFICAS}

ALEXY, Robert. Teoria dos Direitos Fundamentais. 2. ed. São Paulo: Malheiros, 2011. BADARÓ, Gustavo Henrique. Processo Penal. 3. ed. São Paulo: Revista dos Tribunais, 2015.

BARBOSA, Estefânia Maria de Queiroz; LUCCHESI, Guilherme Brenner. A interpretação inconstitucional do STF no HC 126.292. Boletim do Instituto Brasileiro de Direito Penal Econômico, Ano 04, edição especial. 2016, p. 06-07.

BEDÊ JÚNIOR, Américo; SENNA, Gustavo. Princípios do Processo Penal: entre o garantismo e a efetividade da sanção. São Paulo: Revista dos Tribunais, 2009.

BINDER, Alberto M. Introdução ao Direito Processual Penal. Rio de Janeiro: Lumen Juris, 2003.

BITENCOURT, Cezar Roberto. Tratado de Direito penal: Parte Geral, vol. 1. 9. ed. São Paulo: Saraiva, 2004.

BOZZA, Fábio da Silva. Teorias da Pena: Do discurso jurídico à crítica criminológica. Rio de Janeiro: Lumen Juris, 2013.

BRANDÃO, Cláudio. Culpabilidade: sua análise na dogmática e no Direito Penal brasileiro. Ciências Penais, ano 1, n. 1. São Paulo: Revista dos Tribunais, set.dez/2004, p. 171-184.

BUSATO, Paulo César. Direito Penal: Parte Geral. São Paulo: Atlas, 2015.

BUSATO, Paulo César. Fundamentos do Direito penal brasileiro. 3. ed. Curitiba: Edição do Autor, 2012. 
BUSATO, Paulo César. Fundamentos para um Direito Penal Democrático. 4. ed. São Paulo: Atlas, 2013.

BUSATO, Paulo César. Por que, afinal, aplicam-se penas? In: SCHMIDT, Andrei Zenkner. Novos Rumos do Direito Penal Contemporâneo - Livro em homenagem ao Prof. Dr. Cezar Roberto Bittencourt. Rio de Janeiro: Lumen Juris, 2006, p. 511-523.

CARVALHO, Amilton Bueno de. Direito Penal a marteladas: Algo sobre Nietzsche e o Direito. Rio de Janeiro: Lumen Juris, 2013

CASARA, Rubens R. R. Mitologia Processual Penal. São Paulo: Saraiva, 2015.

CASARA, Rubens R. R. Processo Penal do Espetáculo (e outros ensaios). 2. ed. Florianópolis: Tirant lo Blanch, 2018.

COSTA, José de Faria. Direito Penal Económico. Coimbra: Quarteto, 2003.

COSTA, José de Faria. Linhas de direito penal e de filosofia: alguns cruzamentos reflexivos. Coimbra: Coimbra editora, 2005

COUTINHO, Jacinto Nelson de Miranda. A lide e o conteúdo do processo penal. Curitiba: Juruá, 1989.

DAVID, Décio Franco. Delitos de Acumulação e proteção ambiental. Belo Horizonte: Editora D'Plácido, 2017.

DAVID, Décio Franco. Fundamentação principiológica do Direito Penal Econômico: um debate sobre a autonomia científica da tutela penal na seara econômica. 2014.263. Dissertação (Mestrado em Ciência Jurídica) - Universidade Estadual do Norte do Paraná, Jacarezinho, Paraná.

DAVID, Décio Franco. Considerações sobre as garantias do princípio da culpabilidade no Direito Penal Econômico. In: CÂMARA, Luiz Antônio; FONTELLA, Bibiana. (Org.). Revista do Instituto Brasileiro de Direito Penal Econômico. Florianópolis: Empório do Direito, 2016, v. 1, p. 157-188.

DAVID, Décio Franco. Simbolismo: o hambúrguer do marketing político-criminal. Escola Superior de Direito Público. Disponível em: <http://esdp.net.br/simbolismo-o-hamburguer-do-marketing-politico-criminal/>. Acesso em 03 mar. 2017.

DAVID, Décio Franco; ZAMBIAZI, Larissa Horn; DRUMMOND, Fernanda Guerra. Relação entre normas e princípio no Sistema Penal. In: Paulo César Busato. (Org.). Fundamentos de Direito Penal (Série Direito Penal Baseado em Casos). Curitiba: Juruá, 2013, p. 71-92. 
DAVID, Décio Franco; SALOMÃO NETO, Antônio. Reflexões sobre a pena em Hegel. VI Simpósio Internacional de Análise Crítica do Direito, 2017, Jacarezinho. Anais do VI Simpósio Internacional de Análise Crítica do Direito. Jacarezinho: UENP, 2016, p. 120-137.

DAVID, Décio Franco; SALOMÃO NETO, Antônio. Fetichismo e Pena: Reflexões sobre psicanálise no Direito Penal. Revista O Mal-Estar no Direito, v. 2, n. 2. Set./2016, p. 1-17.

DOTTI, René Ariel. Curso de Direito Penal: Parte Geral. 3. ed. São Paulo: Revista dos Tribunais, 2010.

DWORKIN, Ronald. Taking Rights Seriously. Cambridge: Harvard University Press, 1977.

FERRAJOLI, Luigi. Direito e Razão: Teoria do Garantismo Penal. 3. ed. São Paulo: Revista dos Tribunais, 2010.

FERRÉ OLIVÉ, Juan Carlos; NÚNEZ PAZ, Miguel Ángel; OLIVEIRA, Willian Terra de; BRITO, Alexis Couto de. Direito Penal Brasileiro: Princípios fundamentais e sistema. São Paulo: Revista dos Tribunais, 2011.

FLETCHER, George Peter. Basic Concepts of Criminal Law. New York: Oxford University Press, 1998.

FOUCAULT, Michel. Vigiar e Punir: Nascimento da Prisão. 36. ed. Petrópolis: Vozes, 2009.

FREUD, Sigmund. Obras Completas, volume 17: Inibição, sintoma e angústia, O futuro de uma ilusão e outros textos (1926-1929). São Paulo: Companhia das Letras, 2014.

GALVÃO, Fernando. Direito Penal: Parte Geral. 5. ed. São Paulo: Saraiva, 2013.

GIACOMOLLI, Nereu José. O devido processo penal: abordagem conforme a Constituição Federal e o Pacto de São José da Costa Rica. São Paulo: Atlas, 2014.

GRECO, Luís. A ilha de Kant. In: GRECO, Luís; MARTINS, António Carvalho. Direito penal como crítica da pena: estudos em homenagem a Juarez Tavares por seu $70^{\circ}$ aniversário em 2 de setembro de 2012. Madrid: Marcial Pons, 2012, p. 263-279.

HACHEM, Daniel Wunder. Sepultamento da presunção de inocência pelo STF (e os funerais do Estado Democrático de Direito). Direito do Estado, n. 86, 2016. Disponível em: <http://www.direitodoestado.com.br/colunistas/daniel-wunder-hachem/sepultamento-da-presuncao-de-inocencia-pelo-stf-e-os-funeraisdo-estado-democratico-de-direito>. Acesso em 21 ago. 2017. 
HALLSWORTH, Simon. A questão de uma punição pós-moderna. In: CÂNEDO, Carlos; FONSECA, David S (Org.). Ambivalência, contradição e volatilidade no sistema penal. Belo Horizonte: Editora UFMG, 2012, p. 185-209.

LINHARES, Sólon Cícero. Presunção de inocência prevista no artigo $5^{\circ}$ LVII da Constituição Federal - Princípio ou Regra? É possível sua flexibilização? Boletim do Instituto Brasileiro de Direito Penal Econômico, Ano 04, edição especial. 2016, p. 02-03.

LOPES JUNIOR, Aury. Introdução Crítica ao Processo Penal: fundamentos da instrumentalidade constitucional. 5. ed. Rio de Janeiro: Lumen Juris, 2010.

LOPES JUNIOR, Aury. Direito Processual Penal. 11. ed., São Paulo: Saraiva, 2014.

LOPES JUNIOR, Aury. Direito processual penal e sua conformidade constitucional. 8. ed. Rio de Janeiro: Lumen Juris, 2011.

LOPES JUNIOR, Aury; GLOECKNER, Ricardo Jacobsen. Investigação preliminar no processo penal. 6. ed. São Paulo: Saraiva, 2014

OLIVEIRA, Marlus Heriberto Arns de; MICHELOTTO, Mariana Nogueira. Presunção de inocência - avanço ou retrocesso?. Boletim do Instituto Brasileiro de Direito Penal Econômico, Ano 04, edição especial. 2016, p. 11-12.

PRATT, John. O retorno dos "homens carrinho de mão" ou a chegada da punição pósmoderna? In: CÂNEDO, Carlos; FONSECA, David S (Org.). Ambivalência, contradição e volatilidade no sistema penal. Belo Horizonte: Editora UFMG, 2012, p. 128-160.

QUEIROZ, Paulo. Direito Processual Penal. Salvador: Jus Podivm, 2018.

REALE, Miguel. Lições preliminares de Direito. 27. ed. São Paulo: Saraiva, 2010.

RODRIGUEZ, José Rodrigo. Como decidem as cortes? Para uma crítica do Direito (brasileiro). São Paulo: FGV Editora, 2013.

ROSA, Alexandre Morais da; CARVALHO, Thiago Fabres de. Processo penal eficiente e ética da vingança:em busca de uma criminologia da não violência. Rio de Janeiro: Lumen Juris, 2011.

ROXIN, Claus. Derecho Procesal Penal. Buenos Aires: Editores Del Puerto, 2003.

SANTOS, Juarez Cirino dos. Direito Penal: Parte Geral. 2. ed. Rio de Janeiro: Lumen Juris/ICPC, 2007.

SALVADOR NETTO, Alamiro Velludo. Finalidades da Pena: Conceito material de delito e sistema penal integral. São Paulo: Quartier Latin, 2009. 
SILVA, Virgílio Afonso da. Direitos Fundamentais: conteúdo essencial, restrições e eficácia. 2. ed. São Paulo: Malheiros, 2011.

SMANIOTTO, Joao Vitor Passuello; DAVID, Décio Franco. Parcialidade e fetiche: Freud Explica. In: PRONER, Carol et. al. (Org.). Comentários a uma sentença anunciada: o processo Lula. Bauru: Canal 6 Editora, 2017, p. 224-230.

TAFFARELLO, Rogério Fernando. Triste tarde de fevereiro no Supremo Tribunal Federal, ou: “um requiém para a presunção de inocência”. Boletim do Instituto Brasileiro de Direito Penal Econômico, Ano 04, edição especial. 2016, p. 08-10.

TUCCI, Rogério Lauria. Direitos e garantias individuais no processo penal brasileiro. 3. ed. São Paulo: Revista dos Tribunais.

\section{Informações adicionais e declarações dos autores (integridade científica)}

Declaração de conflito de interesses (conflict of interest declaration): os autores confirmam que não há conflitos de interesse na realização das pesquisas expostas e na redação deste artigo.

Declaração de autoria e especificação das contribuições (declaration of authorship): todas e somente as pessoas que atendem os requisitos de autoria deste artigo estão listadas como autores; todos os coautores se responsabilizam integralmente por este trabalho em sua totalidade.

- Décio Franco David: projeto e esboço inicial, levantamento bibliográfico, revisão bibliográfica, redação, revisão crítica com contribuições substanciais, aprovação da versão final.

- Gilson Bonato: revisão bibliográfica, redação, revisão crítica com contribuições substanciais, aprovação da versão final.

Declaração de ineditismo e originalidade (declaration of originality): os autores asseguram que o texto aqui publicado não foi divulgado anteriormente em outro meio e que futura republicação somente se realizará com a indicação expressa da referência desta publicação original; também atestam que não há plágio de terceiros ou autoplágio. 


\section{Dados do processo editorial}

(http://www.ibraspp.com.br/revista/index.php/RBDPP/about/editorialPolicies)

- Recebido em: 25/07/2018

- Controle preliminar e verificação de plágio: 25/07/2018

- Avaliação 1: 03/08/2018

- Avaliação 2: 07/08/2018

- Avaliação 3: 08/08/2018

- Decisão editorial preliminar: 18/08/2018

- Retorno rodada de correções: 09/09/2018

- Decisão editorial final: 22/09/2018
Equipe editorial envolvida

- Editor-chefe: 1 (VGV)

- Editores-associados: 2 (FC e BC)

- Revisores: 3

\section{COMO CITAR ESTE ARTIGO:}

DAVID, Décio F.; BONATO, Gilson. Execução antecipada da pena: entre a garantia do estado de inocência, a coisa julgada e as teorias absolutas da pena. Revista Brasileira de Direito Processual Penal, Porto Alegre, vol. 4, n. 3, p. 11431174, set./dez. 2018. https://doi.org/10.22197/rbdpp.v4i3.180

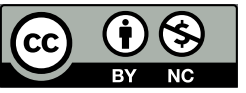

Esta obra está licenciada com uma Licença Creative Commons Atribuição-NãoComercial 4.0 Internacional. 